\title{
WETLAND PLANTS AND THEIR LOCAL USES: OBSERVATIONS FROM RAMPUR GHOL, CHITWAN, NEPAL
}

\author{
DHARMA RAJ DANGOL ${ }^{1} \bowtie$, BIRENDRA GAUTAM $^{2}$ AND BAM BAHADUR OLI $^{3}$ \\ ${ }^{1}$ Natural History Museum, Tribhuvan University, Swayambhu, Kathmandu, Nepal \\ ${ }^{2}$ Central Department of Environmental Science, Tribhuvan University, Kirtipur, Kathmandu, Nepal \\ ${ }^{3}$ Golden Gate International College, Battisputali, Kathmandu, Nepal \\ drdangol@gmail.com
}

\section{ABSTRACT}

This paper is based on the study of wetland plant resources of Rampur Ghol conducted from 2012 to 2014 . This paper documents 117 plant species belonging to 39 families and 92 genera in the area. Dicot species (60 spp.) dominated over the monocots (53 spp.) and pteridophytes (4 spp.). The dominant family was the Poaceae (21 spp.) followed by Cyperaceae (14 spp.), Asteraceae (10 spp.), Scrophulariaceae (8 spp.), Polygonaceae (5 spp.)and Acanthaceae (4 spp.). By life form, emergent species were highest (86\%) compared to submerged (6\%), rooted floating leaved plants $(6 \%)$ and free floating plants $(2 \%)$. These plants had use value of medicine, food (for human, domestic animals, and fish), fuel energy, artifacts, etc. Realizing its contribution along with useful plants, Rampur Ghol area should be conserved for learning and recreation purposes.

Key words: Ethnobotany, floristic diversity, local uses, plant communities, wetlands

\section{INTRODUCTION}

Nepal has over 240 ecologically important wetland ecosystems with diverse flora and fauna including threatened and endangered species (BPP, 1995). These wetland ecosystems consist of abiotic and biotic components (flora and fauna) that interact with each other and provide a variety of services to the local people. Thus, these ecosystems are receiving studies to understand ecological functions and services globally and locally. In Nepal, wetland plants were studied in different types of wetlands such as lakes, ponds, reservoirs, floodplains from lowlands to highlands (Dangol, 2000-2001; Dangol et al., 1995; Siwakoti 2006; Shrestha 1994, 1996; Burlakoti \& Karmacharya, 2004; Jha, 2007; Niroula \& Singh, 2010, 2011; Sah et al., 2002). There were few studies conducted in Rampur Ghol to list plant species and communities (Dangol et al., 1995, Dangol, 1998-1999).

Local communities possess knowledge on the uses of plant species of wetland ecosystems for medicine, thatch/reed harvesting, livestock grazing, and fodder and fuel collection. But the knowledge is confined mostly with elder people. At present, the local knowledge on plant resource use is in danger due to the anthropogenic factors. Therefore, efforts have been made to document the species diversity and their ethnobotanical uses of wetland flora in Nepal (Shrestha, 1994; IUCN, 2004; Panta, 2012). Thus, the need of investigation on wetland plants for sustainable use and management of marsh ecosystem is felt. This study has, therefore, been carried out to investigate the wetland plants with special reference to species inventory and their use values. 


\section{MATERIALS AND METHODS}

Wetland plants were surveyed during different seasons of 2012-2014 at Rampur Ghol and taxonomic information were recorded during the field trips. Plant specimens were collected and taxonomically identified with the help of standard literature (Subramanyam, 1979; Cook, 1996). Voucher specimens have been deposited in the Natural History Museum, Tribhuvan University, Swayambhu, Kathmandu, Nepal. The nomenclature was followed of Press et al. (2000) and Koba et al. (2003).

The indigenous people of Tharu, Darai, Kumal and other local users of the plant resources of Rampur Ghol were consulted to document local uses of each plant resource. Literature on ethnobotany, especially from Nepal and India, were also reviewed for ascertaining the uses of the wetland plants (Dangol, 1996; Dangol \& Gurung, 1991, 1995; Dangol et al., 1995; Bhattarai, 1993a, 1993b; Datta \& Banerjee, 1978; Joshi \& Edington, 1990; Manandhar, 1985, 1989, 1990b, 1993; Neogi et al., 1989; Pal \& Jain, 1989; Prasad \& Abrahma, 1984; Siddiqui \& Hussain, 1991, 1992).

\section{RESULTS}

\section{Floristic diversity}

A total of 117 plants belonging to 92 genera and 39 families were recorded from the study area. The floristic analysis (fig. 1) shows the dicot families (26) dominated over monocot (10) and pteridophytes (3). The distribution of genera was 49 in dicots, 40 in monocots and 3 in pteridophytes. The dicot species (60 spp.) were highest over monocot (53 spp.) and pteridophyte (4 spp.) (fig. 1). The number of species recorded in this study is higher than that of the total number of species reported in previous studies in Koshi Tappu (Shrestha, 1996), Biratnagar (Niroula \& Singh, 2010, 2011), Kirtipur (Manandhar, 2004), Beeshazar (Dangol, 2000-2001, Jha, 2007) and Rampur Ghol (Dangol, 1998-1999).

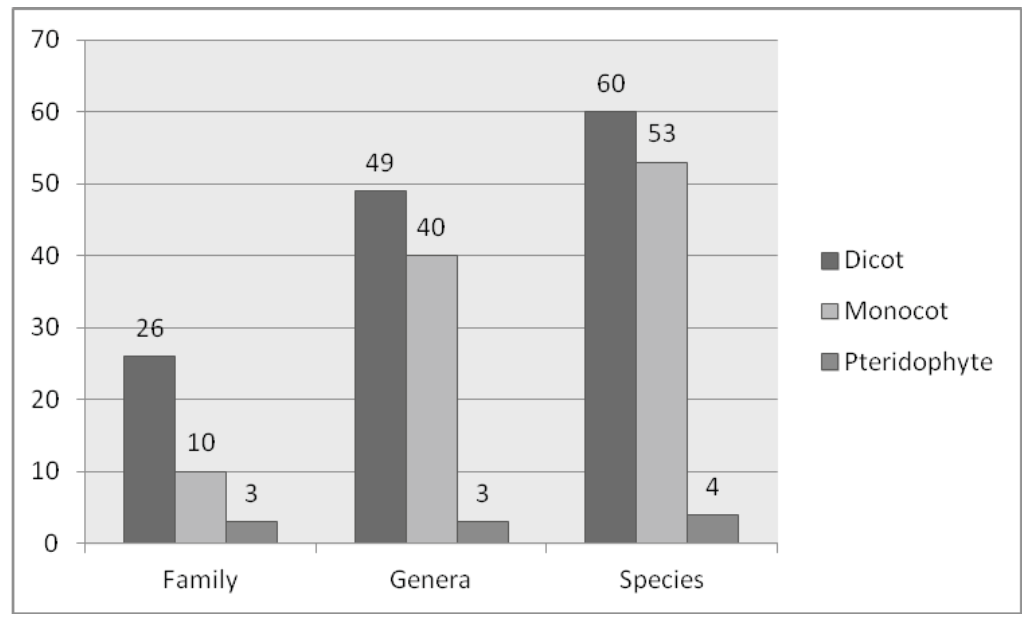

FIG. 1. Number of families, genera and species in Pteridophytes, Dicotyledons (Dicot) and Monocotyledons (Monocot) in Rampur Ghol, Chitwan. 
The highest generic diversity was contributed by the Poaceae (17 genera) followed by Asteraceae (10 genera), Cyperaceae (6 genera), Scrophulariaceae (5 genera), Commelinaceae and Hydrocharitaceae (4 genera each), Acanthaceae, Apiaceae and Verbenaceae (3 genera each), and Polygonaceae, Urticaceae, Alismataceae, Araceae, Fabaceae, Lamiaceae and Lemnaceae (2 genera each). The reset 23 families contributed one genus each (table 1).

The species diversity per family was highest in the Poaceae ( $21 \mathrm{spp}$.) followed by Cyperaceae (14 spp.), Asteraceae (10 spp.), Scrophulariaceae (8 spp.), Polygonaceae (5 spp.), Acanthaceae, Commelinaceae and Hydrocharitaceae (4 spp. each), Apiaceae and Verbenaceae ( 3 spp. each). The rest families contained 1 or $2 \mathrm{spp}$. each (table 1).

Table 1. Floristic analysis of wetland plants of Rampur Ghol, Chitwan district.

\begin{tabular}{|c|c|c|c|c|c|c|c|}
\hline SN & Family & Genus & Species & SN & Family & Genus & Species \\
\hline 1 & Poaceae & 17 & 21 & 21 & Rubiaceae & 1 & 2 \\
\hline 2 & Cyperaceae & 6 & 14 & 22 & Urticaceae & 2 & 2 \\
\hline 3 & Asteraceae & 10 & 10 & 23 & Amaranthaceae & 1 & 1 \\
\hline 4 & Scrophulariaceae & 5 & 8 & 24 & Asclepidiaceae & 1 & 1 \\
\hline 5 & Polygonaceae & 2 & 5 & 25 & Azollaceae & 1 & 1 \\
\hline 6 & Acanthaceae & 3 & 4 & 26 & Bombaceae & 1 & 1 \\
\hline 7 & Commelinaceae & 4 & 4 & 27 & Equisetaceae & 1 & 1 \\
\hline 8 & Hydrocharitaceae & 4 & 4 & 28 & Euphorbiaceae & 1 & 1 \\
\hline 9 & Apiaceae & 3 & 3 & 29 & $\begin{array}{l}\text { Menyanthaceae } \\
\text { (=Gentianaceae) }\end{array}$ & 1 & 1 \\
\hline 10 & Verbenaceae & 3 & 3 & 30 & Hypericaceae & 1 & 1 \\
\hline 11 & Alismataceae & 2 & 2 & 31 & Juncaceae & 1 & 1 \\
\hline 12 & Araceae & 2 & 2 & 32 & Lentibulariaceae & 1 & 1 \\
\hline 13 & Convolvulaceae & 1 & 2 & 33 & Malvaceae & 1 & 1 \\
\hline 14 & Fabaceae & 2 & 2 & 34 & Ranunculaceae & 1 & 1 \\
\hline 15 & Lamiaceae & 2 & 2 & 35 & Sphenocleaceae & 1 & 1 \\
\hline 16 & Lemnaceae & 2 & 2 & 36 & Sterculiaceae & 1 & 1 \\
\hline 17 & Lythraceae & 1 & 2 & 37 & Tiliaceae & 1 & 1 \\
\hline 18 & Onagraceae & 1 & 2 & 38 & Trapaceae & 1 & 1 \\
\hline 19 & Parkeriaceae & 1 & 2 & 39 & Typhaceae & 1 & 1 \\
\hline 20 & Pontederiaceae & 1 & 2 & 40 & Grand Total & 92 & 117 \\
\hline
\end{tabular}

Table 1 reveals that there were 17 families that contributed one species each and 12 families with only $2 \mathrm{spp}$. each. There was only one family with largest species representation i.e. 21. It is clear from the table 1 that the families with fewer species accounted more and families with 
higher species representation were few in number (table 1).

The number of genera and species are equal in 28 families (table 1). Of the total families, 17 families had 1 genus and 1 species, five families had 2 genera and 2 species; 2 families (Commelinaceae and Hydrocharitaceae) had 4 genera and 4 species, and 2 families (Apiaceae and Verbenaceae) had 3 genera and 3 species, and Asteraceae family had 10 genera and 10 species. The rest families (11) had more number of species than genera showing species diversity within the genera.

\section{Life forms}

In the present study (fig. 2), emergent plant species (86\%) dominated over other life forms. This may due to the inclusion of the species from the lake margins, swamplands and moist areas. Other life forms composed of 3 free floating plants (2\%), 7 submerged plants (6\%) and 7 rooted floating-leaved plants $(6 \%)$. The emergent types were confined only in the margin of the Ghol or moist places.

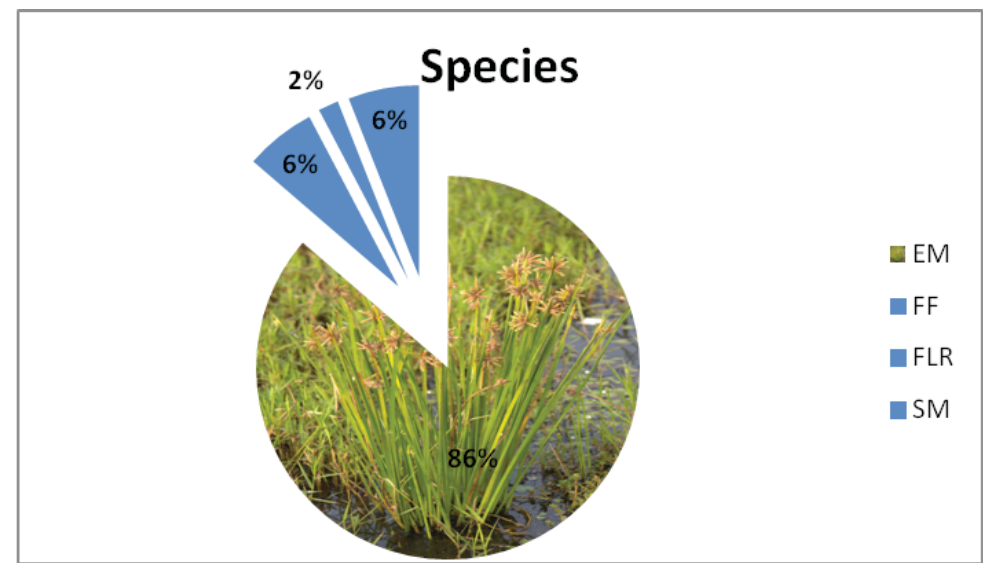

FIG. 2. Life forms of the wetland plants in Rampur Ghol, Chitwan.

\section{DISCUSSION}

\section{Major Macrophytes}

Colocasia esculenta (L.) Schott., and Typha angustata Bosy et Chaub. (fig. 4) was the dominant species in Ghol sector of Aquaculture Department of IAAS or AFU, Schoenoplectus grossus L. and Schoenoplectus mucronatus (L.) Palla were the dominant species at the end of Ghol; Rotala rotundifolia (Buch.-Ham. ex Roxb.) Koehne, Monochoria hastata (L.) Solms. and Veronica anagallis-aquatica L. were the abundant species in head ways to research ponds, and Oenanthe javanica (BI.) DC. was very dominant species in old fields. Vallisneria spiralis L. 
and Nechamandra alternifolius (Roxb. ex Wright) Thwaites were commonly found in the flowing water; Pistia stratiotes L. and Nymphoides cristatum (Roxb.) O. Kuntze as dominant species of stagnant water. Pistia stratiotes L. was also found as most dominant species in the spring and summer rice fields of the study area. Mikania micrantha HBK (fig. 5), Pistia stratiotes L. and Ageratum houstonianum Mill. were observed as dominant species in Rampur Ghol. These species (of Pistia, Mikania and Ageratum) were also reported as the invasive species for Nepal (Tiwari et al., 2005) and other countries. IAAS or AFU needs to initiate some management programs to conserve Ghol, especially from Mikania and Pistia.

\section{Local uses of the wetland plants}

\section{Medical Uses}

Many wetland plants of Rampur Ghol were reported to have medicinal value (appendix 1). The medicinal uses range from fever to complex diseases like leprosy, malaria, rheumatism, jaundice, etc. Fever, dysentery and jaundice were the three health problems with highest number of plant species $(12,5,5 \mathrm{spp}$.) for treatment. The medicinal uses of many plants of Rampur ghol are also found in the reports of previous studies from India (Datta \& Banerjee, 1978).

TABLE 2. Number of medicinal plants used to cure different diseases.

\begin{tabular}{|l|c|l|c|l|c|}
\hline Diseases & $\begin{array}{l}\text { Total } \\
\text { species }\end{array}$ & Diseases & $\begin{array}{c}\text { Total } \\
\text { species }\end{array}$ & Diseases & $\begin{array}{c}\text { Total } \\
\text { species }\end{array}$ \\
\hline Amenorrhoea & 1 & Eye problem & 1 & Pneumonia & 1 \\
\hline Anthelmintic & 2 & Fever & 12 & Purgative & 1 \\
\hline Antidote & 1 & Gastritis problem & 1 & Rheumatism & 3 \\
\hline Aphrodisiac & 1 & Gastro-urinary disease & 1 & Rubefacient & 1 \\
\hline Appetizer & 1 & Genito-urinary troubles & 1 & Scabies & 2 \\
\hline Asthma & 1 & Gonorrhea & 3 & Scorpion sting & 2 \\
\hline Astringent & 1 & Hair tonic & 1 & Skin diseases & 3 \\
\hline Blood problem & 2 & Headache & 3 & Skin parasite & 1 \\
\hline Boils & 3 & Heatstroke & 1 & Sleepless children & 1 \\
\hline Brain tonic & 1 & Hepatic obstructions & 1 & Snakebite & 1 \\
\hline Burns & 1 & Indigestion & 2 & Spleen enlargement & 1 \\
\hline Cholera & 1 & Intestinal cramps & 1 & Spermatorrhoea & 1 \\
\hline Colic & 2 & Itches & 1 & Sprains & 1 \\
\hline Cooling effect & 3 & Jaundice & 5 & Stimulant & 1 \\
\hline Cough and cold & 2 & Laxative & 1 & Stomachache & 2 \\
\hline
\end{tabular}




\begin{tabular}{|l|c|l|c|l|c|}
\hline Cuts and wound & 4 & Leprosy & 1 & Swellings & 2 \\
\hline Demulcent & 1 & Liver disorder & 3 & Syphilis & 1 \\
\hline Diarrhea & 3 & Madness & 1 & Throat infection & 1 \\
\hline Diuretic & 3 & Malaria fever & 1 & Tonic & 3 \\
\hline Drandruff & 1 & Milk secretion & 1 & Toothache & 1 \\
\hline Dysentery & 5 & Muscular pain & 1 & Typhoid & 2 \\
\hline Dyspepsia & 2 & Nervous disorder & 2 & Ulcers & 2 \\
\hline Emetic & 1 & Piles & 4 & Urinary disorders & 3 \\
\hline
\end{tabular}

\section{Wild edibles}

Local communities knew about the uses of wetland plants of Rampur Ghol area. Figure 3 lists 14 species as vegetables, 3 species as edible grains, one as edible nut, one as pickle, one as condiment and two species used as fermenting substrate for making alcoholic beverages. Among the vegetables, corms and tender shoot of Colocasia esculenta (L.) Schott. and young shoots of Ipomoea aquatica Forssk. are sold in local market. The grains of Echinochloa colona (L.) Link, E. crus-galli (L.) P. Beauv., and Setaria glauca (L.) P. Beauv. are edible and used chiefly as famine food.

\section{Fodders, Fish Food and Poisonous Plants}

Most of wetland plants are useful as the feed for domestic animals and fish (fig. 3). The members of the Poaceae, Cyperaceae and Commelinaceae are the chief source of forage for domestic animals (appendix I). A total of 56 plant species were reported as fodder for domestic animals and 7 species as fish food. The highest number of plant species was also reported as fodder by Niroula \& Singh (2010) for Biratnagar and adjoining areas. However, some plants such as Ageratum houstonianum Mill. and Ipomoea carnea Jacq. are poisonous to livestock or some (Polygonum barbatum L., Polygonum glabrum Willd., Polygonum hydropiper L., Polygonum lapathifolium L.) to the fish.

\section{Aesthetic plants}

Nine species were reported as the plants with aesthetic value. Some plants like Ipomoea aquatic Forssk., Nymphoides cristatum (Roxb.) O. Kuntze, Trapa bispinosa Roxb. and Rotala rotundifolia (Buch.-Ham. ex Roxb) Koehne have beautiful flowers that add the beauty to the Ghol. The blue flowers of the Monochoria hastata (L.) Solms. and Monochoria vaginalis (Burm. f.) Presl, light blue flowers of Chromalaena odorata (L.) R. M. King, white triumphet flowers of Ipomoea carnea Jacq. or yellow spikes of many sedges are also looking attractive. Vallisneria spiralis L. are also beautiful when these are swinging inside the flowing water. In addition, emerging yellow flowers of the submerged carnivorous plant, Utricularia aurea Lour. are also attractive to visitors' mind to think about the functional relation of the plant with the nature. Besides these, Hydrilla verticellata (L. f.) Royle plant is also used as decorating plant material and fish feed in the aquarium (Datta \& Banerjee, 1978). 


\section{Other uses}

Wetland plants were also reported as fuel (3 spp.), hedge (1 sp.), manure (2 spp.), lawn (1 sp.), mat (4 spp.), boat construction (1 sp.), broom (1 sp.), paper making (2 spp.), stuffing material (3 spp.), thatching, (4 spp.), fiber (1 sp.), and religious (1 sp.). The mats prepared from Typha angustata Bosy et Chaub. is considered as quality mats, locally called "gundri", chiefly made by Tharus and Darai tribes of Chitwan. Inflorescence of Imperata cylindrica (L.) P. Beauv. and flosses of Bombax ceiba L. and Calotropis gigantea (L.) Drynand are used as stuffing material for pillows. Typha angustata Bosy et Chaub., Imperata cylindrica (L.) P. Beauv. and Saccharum spontaneum L. are used as thatching material.

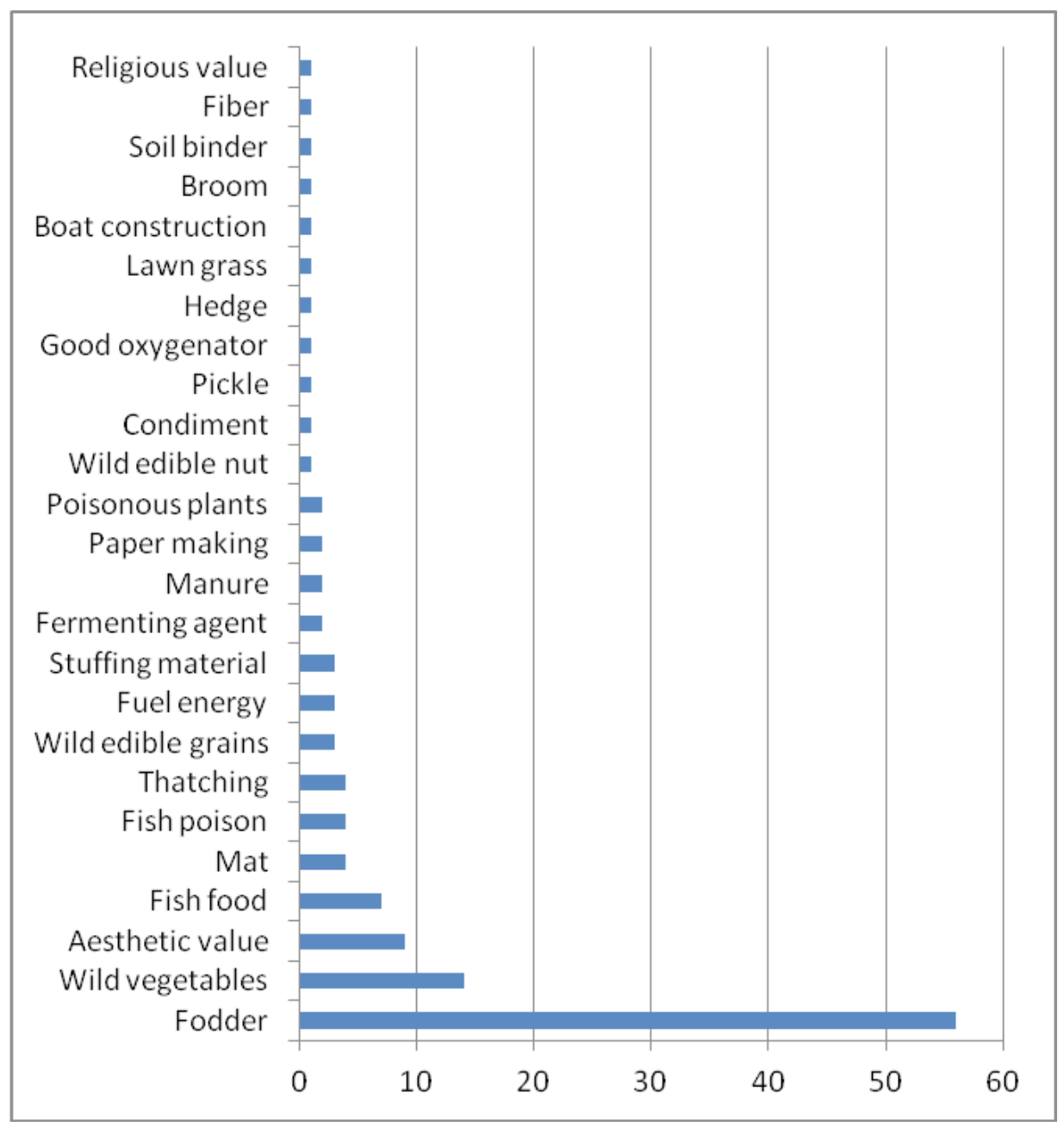

FIG. 3. Local uses of wetland plants of Rampur, Chitwan, Nepal. 


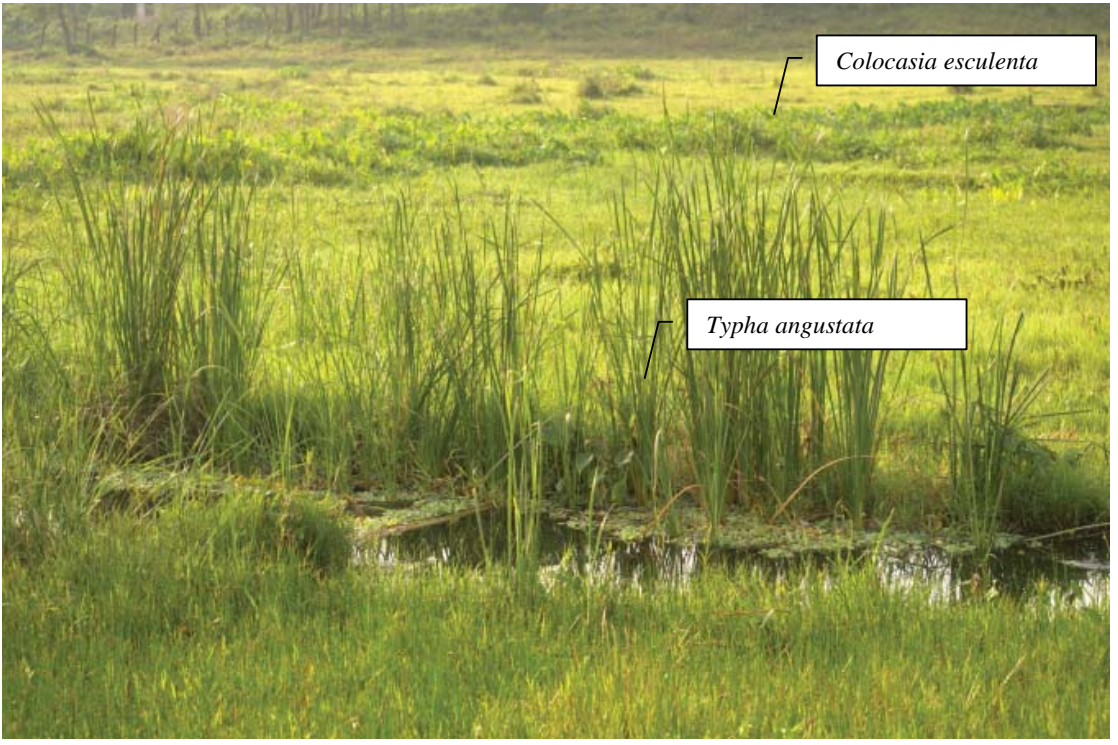

FIG. 4. Dominant species in Rampur Ghol \{Colocasia esculenta (L.) Schott. and Typha angustata Bosy et Chaub.\}.

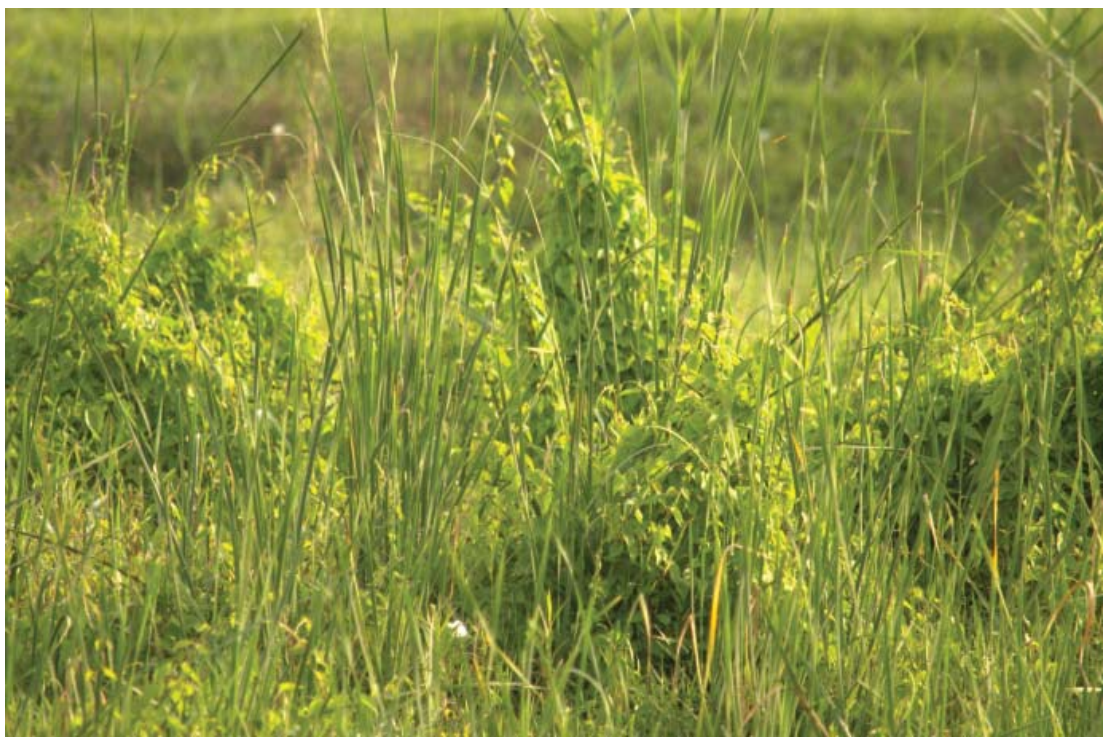

FIG. 5. Mikania micrantha HBK (Lahare banmara) climbing on the Typha angustata Bosy et Chaub. plants in Rampur Ghol. 
The present study reveals that Rampur Ghol is the habitat for wetland plants and local people have knowledge and skill on the uses of plant resources in the studied area. The uses plants and traditional practices can play a significant role in the socio-cultural life of local communities. But the trend of decline of useful native species, increase of unsustainable anthropogenic practices and encroachment and spreading of invasive species (Mikania micrantha HBK and Pistia stratiotes L.) show that action for conservation is urgently needed. Therefore, priority should be given to implement conservation activities with integrated approach for sustainable development. Realizing the location of Rampur Ghol, academic institutions need to initiate learning activities, such as plant species database preparation, habitat characterization, identification of potential species for various economic uses and formulation and implementation of plan of actions taking consideration of the needs of people and sustainable management of the wetlands. Detail study of the aquatic and semi-aquatic plant diversity need to be carried out for preparing plant identification manual. It is the time to conduct comprehensive ethnobotanical studies of the aquatic plants collaborating with the local people of the district so that the traditional knowledge on biodiversity and environment for conservation and management of nature.

\section{ACKNOWLEDGEMENTS}

We would like to thank University Grants Commission, Bhaktapur for financial support to conduct Rampur Ghol Project and Prof. Dr. Keshab Shrestha, Natural History Museum, Tribhuvan University, Swayambhu, Kathmandu and Mrs. Nirmala Joshi, Department of Plant Resources, Ministry of Forests and Soil Conservation, Thapathali for reviewing the manuscript. We would also like to thank local informants for providing information on their knowledge and skill on the use of wetland plants and Mr. Daya Bajracharya, post-graduate student of Department of Environmental Science of the Institute of Agriculture and Animal Science, Tribhuvan University for his help in field work.

\section{REFERENCES}

Bhattarai, N K (1993a) Folk herbal medicines of Dolakha district, Nepal. Fitoterapia LXIV(5): 387-395.

Bhattarai, N K (1993b) Medical ethnobotany in the Rapti zone, Nepal. Fitoterapia LXIV(6): 483-493.

BPP (1995) Biodiversity assessment of Terai wetlands. HMGN/Government of the Netherlands. Biodiversity Profile Project. Technical Publication No 1, Dec 1995, 417/4398.2.

Burlakoti, C; Karmacharya, S B (2004) Quantitative analysis of macrophytes of Beeshazar Tal, Chitwan, Nepal. Himalayan Journal of Sciences 2(3): 37-41.

Cook, C D K (1996) Aquatic and wetland plants of India: a reference book and identification manual for the vascular plants found in permanent or seasonal fresh water in the subcontinent of India south of the Himalayas. New York: Oxford University Press Inc.

Dangol, D R; Gurung, S B (1991) Ethnobotany of the Tharu tribes of Chitwan district, Nepal. Int. J. Pharmacognosy 29(3): 203-209.

Dangol, D R; Gurung, S B (1995) Ethnobotanical studies of Darai tribe in Chitwan district, Nepal. Research Report: NEMP/IUCN \& NAHSON Chitwan Unit, Nepal; pp. 14-52.

Dangol, D R (2000-2001) Aquatic plant resources and their uses: observation from Beesh Hazar Lake, 
Chitwan. Journal of Institute of Agriculture and Animal Science 21-22: 119-133.

Dangol, D R (1998-1999) An inventory of plant biodiversity of Rampur, Chitwan, Nepal. Journal of Institute of Agriculture and Animal Science 19-20: 27-40.

Dangol, D R; Gurung, S B; Bhandary, A(1995) Studies on plant communities of natural and man-engineered ecosystems in the Chitwan Valley, Nepal. A final report submitted to NEMP-IUCN, Nepal; pp. 116-162.

Datta, S C; Banerjee, A K (1978) Useful weeds of west Bengal rice fields. Economic Botany 32: 297-310. IUCN (2004) A review of the status and threats to wetlands in Nepal. Kathmandu: IUCN Nepal, Kathmandu. Jha, S (2007) Phytodiversity in Beeshazar lake and surrounding landscape system. Our Nature 5: 41-51. Joshi, A R; Edington, J M (1990) The use of medicinal plants by two village communities in the Central Development Region of Nepal. Economic Botany 44(1): 71-83.

Koba, H; Akiyama, S; Endo, Y; Ohba, H (2003) Name list of flowering plants and gymnosperms of Nepal. Tokyo, Japan: The University Museum, University of Tokyo.

Manandhar, N P (1985) Ethnobotanical note on certain medicinal plants used by Tharus of Dang-Deokhuri district, Nepal. Int. J. Crude Drug Res. 23(4): 153-159.

Manandhar, N P (1989) Medicinal plants used by Chepang tribes of Makawanpur district, Nepal. Fitoterapia LX(1): 61-68.

Manandhar, N P (1990) Traditional phytotherapy of Danuwar tribes of Kamalakhonj in Sindhuli district. Fitoterapia LXI(4): 325-331.

Manandhar, N P (1993) Ethnobotanical note on folklore remedies of Baglung district, Nepal. Contributions to the Nepalese Studies 20(2): 183-196.

Manandhar, S (2004) Weed ecology of paddy field at Kirtipur, Kathmandu. M.Sc. dissertation, Central Department of Botany, Tribhuvan University, Kirtipur, Kathmandu, Nepal.

Neogi, B; Prasad, M N V; Rao, R R (1989) Ethnobotany of some weeds of Khasi and Garo hills, Meghalaya, Northeastern India. Economic Botany 43(4): 471-479.

Niroula, B; Singh, K L B (2010) Contribution to aquatic macrophytes of Biratnagar and adjoining areas, eastern Nepal. Ecoprint 17: 23-34.

Niroula, B; Singh, K L B (2011) Seasonal variation in importance value index (IVI), diversity indices and biomass of aquatic macrophytes in Biratnagar and adjoining areas, eastern Nepal. Nepalese Journal of Biosciences 1: 1-7.

Pal, D C; Jain, S K (1989) Notes on Lodha medicine in Midnapur district, west Bengal, India. Economic Botany 43(4): 464-470.

Panta, S R (2012) An inventory of plant and their uses from Devriya wetland of Kailali district Nepal. Central Department of Botany, Tribhuvan University, Kirtipur, Kathmandu, Nepal.

Prasad, P N; Abraham, Z (1984) Ethnobotany of the Nayadis of north Kerala. J. Econ. Tax. Bot. 5(1): 41-48.

Press, J R; Shrestha, K K; Sutton, D A (2000) Annotated checklist of the flowering plants of Nepal. The Natural History Museum, London, UK.

Sah, J P; Singh, R L \& Bhatta, N (2002) Floristic diversity and use of plants in Ghodaghodi Lake area, Nepal. Journal of Natural History Museum 21: 243-266.

Shrestha, P (1994) Wetland flora of Nepal. In Bhandari, B; Shrestha, T B; McEschern, J (eds) Safeguarding 
wetlands in Nepal. Proceedings of the National Workshop on Wetlands Management in Nepal. IUCN/ Nepal, Kathmandu.

Shrestha, $P$ (1996) Diversity of aquatic macrophytes in the Koshi Tappu Wildlife Reserve and Surrounding areas, eastern Nepal. In Jha, P K; Ghimire, G P S; Karmacharya, S B; Lacoul, P (eds) Environment and biodiversity in the context of south Asia. Ecological Society (ECOS), Kathmandu, Nepal; pp. 203-211.

Siddiqui, M B; Hussain, W (1991) Traditional treatment of diarrhoea and dysentery through herbal drugs in rural India. Fitoterapia LXII(4): 325-329.

Siddiqui, M B; Hussain, W (1992) Some aquatic and marshy land medicinal plants from Hardoi district of Uttar Pradesh. Fitoterapia LXII(3): 245-248.

Siwakoti, M (2006) An overview of floral diversity in wetlands of Terai region of Nepal. Our Nature 4: 83-90.

Subramanyam, K (1979) Aquatic Angiosperms. Botanical Monograph No. 3. Council of Scientific and Industrial Research, New Delhi, India.

Tiwari, S; Adhikari, B; Siwakoti, M; Subedi, K (2005) An inventory and assessment of invasive alien species of Nepal. IUCN Nepal, Kathmandu. 


\section{Appendix I.}

Wetland plants and their uses in Rampur, Chitwan, Nepal.

(EM=emergent, $\mathrm{SM}=$ submerged, $\mathrm{FF}=$ free floating, and $\mathrm{FLR}=$ floating leaved rooted aquatics).

Adenostemma lavenia (L.) O. Kuntze, Asteraceae, EM, Herb with white capitulum. Fodder. Aeschynomene indica L., Fabaceae, EM, Herb with pale yellow flowers. It is used as fodder. Ageratum houstonianum Mill., "Gandhe", Asteraceae, EM, Erect or creeping at the base and rooting annual or short-lived perennial herb. It is poisonous to livestock. Leaf juice applied to treat cuts and wound.

Alisma plantago-aquatica L., Alismataceae, EM, Herb with white flowers.

Alternanthera sessilis (L.) DC., "Saranchi sag", Amaranthaceae, EM Annual or perennial herb. Tender plants are used as vegetable in India (Datta \& Banerjee, 1978; Prasad \& Abraham, 1984). The plant juice is used in treating scabies and urination disorder (Manandhar, 1989) and root juice to treat dysentery (Manandhar, 1990). The plants are also used as a febrifuge, for the eyes, a cooling hair wash, a remedy against intestinal cramps, and a cure for snakebite (Datta \& Banerjee, 1978).

Amischophacelus axillaris (L.) Rolla Rao et Kammathy, "Kane", Commelinaceae, EM, A succulent annual plant. It is used as fodder.

Axonopus compressus (Sw.) P. Beauv., "Makaipate banso", Poaceae, EM, Perenial herb, stem compressed. Fodder, Lawn.

Azolla pinnata R. Br., Azollaceae, FF, Small $\mathrm{N}_{2}$ fixing plants with high nitrogen contents. Manure.

Barleria cristata L., Acanthaceae, EM, Herb with blue attractive flowers. Root juice in case of indigestion (Manandhar, 1993).

Bidens pilosa L., "Kalo kuro", Asteraceae, EM, Herb with black sticky fruits. Fodder.

Bombax ceiba L., "Simal", Bombaceae, EM, A tall tree with red flowers and white cotton stuff. Stuffing material, fodder, wood for boat construction.

Caesulia axillaris Roxb., "Thuk jhar", Asteraceae, EM, Succulent herb with axillary inflorescence. Fodder for animals. Whole plant tonic to domestic animals (Manandhar, 1990).

Calotropis gigantea (L.) Drynand., "Aank", Asclepidiaceae, EM, A shrub with milky juice, found on the bank of ghol, Stuffing material. Milky juice with medicinal value for treating sprains.

Centella asiatica (L.) Urb., "Ghod tapre". Apiaceae, EM, Perennial creeping herb. Leaves are edible as vegetable. It is used as fodder for increasing secretion of milk in cows (Datta \& Banerjee, 1978). It is reported as insecticide (Datta \& Banerjee, 1978). Plant juice is applied to suppress muscular pain and swellings and also taken in fever, diarrhea and dysentery (Bhattarai, 1993b; Manandhar, 1990, 1993). Leaf juice is given to treat nerve and blood diseases (Manandhar, 1990; Prasad \& Abraham, 1984). The leaf juice is orally taken to relieve throat infection (Bhattarai, 1993a). 
Centranthera cochinchinensis (Lour.) Merr., Scrophulariaceae, EM, Herbs with hispid hairs. Fodder.

Ceratopteris pteridoides (Hooker) Hieronymus,"Mujurkhute jhar", Parkeriaceae, EM, very succulent. Fodder.

Ceratopteris thalictroides (L.) Brongn., "Pani dhaniya", Parkeriaceae, EM, Soft fleshy plants used for vegetables.

Chromalaena odorata (L.) R. M. King, “Banmara”, Asteraceae, EM, A diffuse scrambling, tall shrub. Fuel. Flowers are beautiful having aesthetic value. Leaf juice is used to treat cuts and wounds (Dangol \& Gurung, 1995; Manandhar, 1989; 1990; Neogi et al., 1989).

Chrysopogon aciculatus (Retz.) Trin., "Kuro”, Poaceae, EM, Perennial herb. Fodder.

Clerodendrum viscosum Vent., "Bhanthi", Verbenaceae, EM, shrub. Leaves as cover and bed while preparing local beer by Darai community, flowers with aesthetic value.

Colocasia esculenta (L.) Schott., "Karakale”, Araceae, EM, Fleshy perennial plant. Leaves and corm as vegetable.

Commelina diffusa L., "Kane", Commelinaceae, EM, Annual herb with blue flowers. The plants are used as fodder, vegetable, and medicinally in boils, burns, and itches (Datta \& Banerjee, 1978).

Cynodon dactylon (L.) Pers., "Dubo", Poaceae, EM, perennial herb. Fodder, religious value.

Cyperus compactus Retz., "Mothe”, Cyperaceae, EM, Perennial herb. Fodder.

Cyperus distans L. f., "Mothe", Cyperaceae, EM, Herb used as fodder.

Cyperus globosus All., "Mothe", Cyperaceae, EM, Herb used as fodder.

Cyperus halpan L., "Mothe", Cyperaceae, EM, Herb used as fodder.

Cyperus iria L., "Mothe", Cyperaceae, EM, Annual herbaceous sedge. The plant is used as fodder. It is also used to make mats. The plant is astringent, stimulant, stomachic and tonic (Datta \& Banerjee, 1978).

Cyperus sanguinolentus Vahl, Cyperaceae, EM, Sedges with dark red spikes. Fodder.

Dysophylla auriculata (L.) Blume, Lamiaceae, EM, Erect herb with hairs on stem, Fodder.

Echinochloa colona (L.) Link, "Sama", Poaceae, EM, Erect or prostrate annual grass. It is a good fodder. Seeds are famine food (Datta \& Banerjee, 1978; Neogi et al., 1989). In Indonesia, the young shoots are eaten (Datta \& Banerjee, 1978).

Echinochloa crus-galli (L.) P. Beauv., "Sama”, Poaceae, EM, Robust, tufted annual grass. It is also a good fodder for livestock. Grains are edible.

Echinochloa glabrescens Munro ex Hook. f., "Sama", Poaceae, EM, Tall grass. It is used as fodder.

Eclipta prostrata (L.) L., "Bhangariya”, Asteraceae, EM, Annual or perennial herb. It is used as fodder. The young plant parts used as vegetables. The plant paste or juice is applied in 
cuts and wounds (Manandhar, 1990, 1993). Root juice given to children in case of fever (Manandhar, 1990), seed paste to treat headache, toothache and rheumatism (Manandhar, 1985). In combination with aromatic, the juice is given in cases of catarrhal jaundice (Datta \& Banerjee, 1978). The leaf is a remedy for scorpion sting (Datta \& Banerjee, 1978).

Enydra fluctuans Lour. Asteraceae, EM, A succulent perennial herb. It is used as vegetable with blood purifying properties (Neogi et al., 1989). The plant is useful in the torpidity of liver, skin and nervous disorders (Datta \& Banerjee, 1978).

Equisetum debile Roxb. "Kurkure", Equisetaceae, EM, Perennial plant. Leaf paste on bone fracture.

Eragrostis gangetica (Roxb.) Steudel, "Banso", Poaceae. EM, Perennial herb. Fodder.

Fimbristylis dichotoma (L.) Vahl, "Mothe", Cyperaceae, EM, Annual erect sedge. It is uses as fodder.

Fimbristylis miliacea (L.) Vahl, "Mothe", Cyperaceae, EM, Erect, tufted sedge. It is given as fodder.

Floscopa scandens Lour., Commelinaceae, EM, Moist loving plant with rose color flowers. Fodder.

Fuirena umbellata Roxb., "Mothe", Cyperaceae, EM, herb with grey spikes. Fodder.

Gonostegia pentandra (Roxb.) Miq., Urticaceae, EM, Slender plant with red stem. Fodder.

Hedyotis corymbosa (L.) Lam., Rubiaceae, EM, Semi-aquatic herb with small white flowers in axillary positions. The plant juice is given in cases of fever, jaundice and the diseases of the liver (Datta \& Banerjee, 1978).

Hedyotis diffusa Willd., Rubiaceae, EM, Small wiry herb with white flowers.

Hemarthria compressa (L.) R. Br., "Ghode dubo". Poaceae, EM, Ascending herb. It is a fodder. Hydrilla verticillata (L. f.) Royle, "Jhyau". Hydrocharitaceae, SM, Submerged aquatics. It is used as fodder, green manure, good oxygenator, and is a fish food (Datta \& Banerjee, 1978).

Hydrocotyle sibthorpoides Roxb. ex DC., "Sano ghodtapre”, Apiaceae, EM, prostrate herb. Medicinal herb for treating urinary problem.

Hygrophila auriculata (Schum.) Heine, Acanthaceae, EM, Spiny herb. Seed decoction is used in spermatorrhoea, gonorrhoea and urinary diseases (Siddiqui \& Husain, 1992).

Imperata cylindrica (L.) P. Beauv., "Siru". Poaceae, EM, Perennial grass. It is chiefly used as fodder, thatch grass and soil binder. Flossy inflorescence as stuffing material for pillows and cushion and plants for paper making and fuel. The root juice is given to treat gastritis troubles (Manandhar, 1993). The roots are used for fumigation of piles (Pal \& Jain, 1989).

Ipomoea aquatica Forssk., "Kalmi sag”. Convolvulaceae, FF, Perennial floating fleshy herb. Tender shoots are used as vegetable. Flowers with aesthetic value. The plant juice is used as an emetic in cases of arsenic or opium poisoning (Datta \& Banerjee, 1978). The plant is used for piles (Datta \& Banerjee, 1978). Fresh leaf juice is used in case of liver complaints 
(Siddiqui \& Husain, 1992).

Ipomoea carnea Jacq.=I. fistulosa L., "Behaya". Convolvulaceae, EM, Tall shrub with pinkish white flowers. This plant is poisonous to livestock and used as hedge to protect the croplands. Flowers with aesthetic value. The plant juice is applied between the toes to heal the wounds (Manandhar, 1985).

Isachne globosa (Thunb.) O. Kuntze, Poaceae, EM, A herb. Grass used for fodder.

Juncus prismatocarpus R. Br., "Gunda", Juncaceae, SM, Small herb with white globose heads. Uses not known.

Justicia procumbens L. var. simplex (D. Don) Yamazaki, Acanthaceae, EM, A herb.

Justicia quinqueangularis Koen., Acanthaceae, EM, Herb with pink flowers in the spike. The leaves are consumed as vegetable.

Kyllinga brevifolia Rottb., Cyperaceae, EM, Perennial herb. Fodder.

Lantana camara L., Verbenaceae, EM, shrub with colorful flowers. Fuelwood.

Leersia hexandra Sw., "Karaute jhar", Poaceae, EM, A tall perennial, tufted aquatic or swampy grass. Fodder for livestock.

Lemna perpusilla Torrey, Lemnaceae, FF, A minute plant on the water surface.

Limnophila indica (L.) Druce, Scrophulariaceae, SM, Aquatic or semi-aquatic herb. The leaves are consumed as vegetables. An infusion of leaves is given for dyspepsia and dysentery (Datta \& Banerjee, 1978).

Limnophila rugata (Roth) Merr., Scrophulariaceae, EM, Herb with red flowers. Fodder.

Lindernia anagallis (Burm. f.) Pennell, Scrophulariaceae, EM, Herb with purple flowers on the axillary positions.

Lindernia oppositifolia (L.) Mukerjee, Scrophulariaceae, EM, Small herb with white flowers. Lindernia pusilla (Willd.) Bold, Scrophulariaceae, EM, Small herb with hairy calyx and pedicels.

Liphocarpa chinensis (Osb.) Kern, "Dalle mothe", Cyperaceae, EM, Perennial herb with globose spikes. Fodder.

Ludwigia hyssopifolia (G. Don) Exell, "Lwang jhar", Onagraceae, EM, Annual herb with yellow flowers. Fodder.

Ludwigia perennis L., "Lwang jhar", Onagraceae, EM, Annual herb with yellow flowers. The plant is boiled in oil and applied externally to reduce fever (Datta \& Banerjee, 1978).

Melochia corchorifolia L., Sterculiaceae, EM, Erect herb with light pink flowers. Fodder.

Mikania micrantha HBK, "Lahare banmara", Asteraceae, EM, generally terrestrial herbaceous climbers, recorded from $\mathrm{Ghol}$ and spring rice fields. Rhinos sometimes eat in Chitwan National Park. 
Monochoria hastata (L.) Solms., "Karkale jhar", Pontederiaceae, EM, A smooth, erect aquatic perennial herb. Young plants are used as vegetable, flowers with aesthetic value.

Monochoria vaginalis (Burm. f.) Presl, "Karkale jhar", Pontederiaceae, FLR, Aquatic herb with purple or blue flowers. It is reported as vegetable, flowers with aesthetic value.

Murdannia nudiflora (L.) Brenan, "Sano kane". Commelinaceae, EM, Annual herb with pale purple flowers. Fodder.

Nechamandra alternifolius (Roxb. ex Wight) Thwaites, Hydrocharitaceae, SM, delicate herb. Fish food.

Nymphoides cristatum (Roxb.) O. Kuntze, Menyanthaceae (=Gentianaceae), FF, Free floating aquatic. Leaves, stem and fruit are consumed after boiling or making curry. Flowers with aesthetic value. The plant is used medicinally in jaundice and fevers. The seeds are anthelmintic. Decoction is used as a wash for skin parasites (Datta \& Banerjee, 1978).

Oenanthe javanica (BI.) DC., Apiaceae, EM, A herb growing on marshy places. Leaves as condiments.

Ottelia alismoides (L.) Pers., "Jal palak". Hydrocharitaceae, SM, Submerged herb with white flowers. It is a fish food (Datta \& Banerjee, 1978). Leaves are consumed as vegetable (Datta $\&$ Banerjee, 1978). Poultice of the leaves is used on arms and legs during high fever (Siddiqui \& Husain, 1992). The plants are rubefacient (Datta \& Banerjee, 1978).

Panicum repens L., Poaceae, EM, Erect, creeping perennial grass. Fodder.

Paspalum distichum L., Poaceae, EM, Perennial herb. Fodder.

Paspalum scrobiculatum L., "Kode banso" "Mane banso". Poaceae, EM, A herb. It is used as fodder. Plant sap is useful for scorpion sting (Datta \& Banerjee, 1978). The decoction of root and black peppers with a pinch of common salt is useful for typhoid fever (Pal \& Jain, 1989).

Phragmites karka (Retz.) Trin. ex Steud., "Narkat", Poaceae, EM, Herb with woody stems. Fodder.

Phyla nodiflora (L.) Greene, Verbenaceae, EM, Creeping herb with erect flowering shoots. Squeezed plant is inhaled to treat cough and cold. In Sri Lanka, the leaves are eaten, whereas in the Philippines an infusion of the leaves is taken as tea (Datta \& Banerjee, 1978). The plant possesses cooling, diuretic, digestive and febrifuge properties (Datta \& Banerjee, 1978). The plant paste is applied as a suppurate for boils, chronic indolent ulcers and swollen neck glands (Datta \& Banerjee, 1978). Plant juice/paste is used to relieve fever and headache (Manandhar, 1985, 1989).

Phyllanthus urinaria L., "Amala jhar, Bhui amala". Euphorbiaceae, EM, Annual erect herb with very small flowers on the leaves. The plant is given as fodder. Plant is used in gonorrhoea and other genito-urinary troubles, and root to sleepless children (Datta \& Banerjee, 1978).

Pistia stratiotes L., "Panikobi", Araceae, FF, Foliage attractive. The leaves are used in the treatment of dysentery, asthma, coughs, and skin diseases (Datta \& Banerjee, 1978).

Pogostemon auriculata (L.) Blume, Lamiaceae, EM, Erect hairy herb. Fodder. 
Polygonum barbatum L., "Pire jhar", Polygonaceae, EM, Semi-aquatic herb with white flowers. The whole plant is used as piscicide. Root and shoot decoction is given in case of colic and purgative and also used to wash ulcers (Siddiqui \& Husain, 1992). Root paste is applied on scabies (Manandhar, 1990).

Polygonum glabrum Willd., "Pire jhar", Polygonaceae, EM, Semi-aquatic herb. Infusion of leaves is used in colic, leaf juice in pneumonia, rootstock decoction in case of piles and jaundice (Siddiqui \& Husain, 1992).

Polygonum hydropiper L., "Pire jhar". Polygonaceae, EM, Herb with pungent smell, a fish poison (Dangol \& Gurung, 1995; Datta \& Banerjee, 1978; Neogi et al., 1989). It is poisonous to livestock (Datta \& Banerjee, 1978). Seeds are used to relieve stomachache (Joshi \& Edington, 1990).

Polygonum lapathifolium L., "Pire jhar", Polygonaceae, EM, A tall herb, Fish poison.

Pouzolzia zeylanica (L.) Benn. et Brown, “Chiple jhar”, Urticaceae, EM, Herb. Medically important for removing dandruff.

Ranunculus sceleratus L., "Jal dhaniya”. Ranunculaceae, EM, Erect annual herb. Paste of seeds is used in skin diseases.

Rotala indica (Willd.) Koehn, Lythraceae, EM, Annual herb. Fish food.

Rotala rotundifolia (Buch.-Ham ex Roxb.) Koehne, Lythraceae, EM, Annual herb with attractive rosy flowers.

Rottboellia exaltata L. f., Poaceae, EM, Erect or ascending, strongly tufted, annual grass. Water buffaloes like the grass.

Rumex dentatus L., "Ban palungo". Polygonaceae, EM, Erect, annual herb. The young plants are used vegetable.

Saccharum spontaneum L., "Kans". Poaceae, EM, Perennial herb. It is used as fodder and for thatching roofs, for paper pulp and fuel (Dangol \& Gurung, 1995). Medicinally, it is aphrodisiac and laxative (Datta \& Banerjee, 1978).

Sacciolepis indica (L.) A. Chase, Poaceae, EM, Annual herb. Fodder.

Sagittaria guayanensis Kunth, "Karkale jhar". Alismataceae, FLR, Floating leaved annual herb. Plant decoction is applied over body to control fever.

Sarothra laxa (BI.) Kimura, Hypericaceae, EM, A small herb with yellow flowers. Fodder.

Schoenoplectus grossus L., "Thulo mothe", Cyperaceae, EM, erect herb. Fodder, stems for making mat.

Schoenoplectus juncoides (Roxb.) Palla, "Suire mothe", Cyperaceae, EM, Tufted herb of wetlands. Used for fodder.

Schoenoplectus mucronatus (L.) Palla, "Mothe", Cyperaceae, EM, Tufted herbs growing in wetlands. Used for making mat.

Scoparia dulcis L., "Chini jhar", Scrophulariaceae, EM, Herb with small white flowers. Stem 
pieces are chewed as a remedy for cooling effect (Dangol \& Gurung, 1991, 1995). Whole plant juice is given for typhoid and root juice for diarrhea (Manandhar, 1990). Root paste is given to relieve fever (Manandhar, 1989).

Setaria glauca (L.) P. Beauv., "Bale banso". Poaceae, EM, Erect annual grass. Fodder, grains edible (Datta \& Banerjee, 1978).

Setaria pallide-fusca (Schum.) Stapf. et C.E. Hubb., "Bale banso", Poaceae, EM, Annual herb. Fodder for livestock.

Sida acuta L., Balu, Malvaceae, EM, strong plant, leaves medicinally used for boils, stems for making broom.

Smithia sensitiva Ait., Fabaceae, EM, A sensitive legume. It is used to make a good hay. The leaves are consumed as vegetable (Datta \& Banerjee, 1978). A lotion is useful for headache (Datta \& Banerjee, 1978). Root juice is given to fever (Manandhar, 1990).

Sphenoclea zeylanica Gaertn., Sphenocleaceae, EM, Succulent erect, annual plant. The plants are edible (Datta \& Banerjee, 1978).

Spilanthus uliginosa Swarts, "Marethi", Asteraceae, EM, Herb with yellow heads. Inflorescence used to make pickle.

Spirodela polyrrhiza (L.) Schleid., Lemnaceae, FF, Small plants. Fish food.

Themeda arundinacea (Roxb.) Ridley, "Dhadhi”, Poaceae, EM, A tall grass used for thatching and fodder.

Trapa bispinosa Roxb., "Singada", Trapaceae, FF, Aquatic plant. Nuts are edible. Flowers with aesthetic value.

Truimfetta annua L., "Dalle kuro”, Tiliaceae, EM, erect herb with yellow flowers. Bark for fiber. Typha angustata Bosy et Chaub., "Pater", Typhaceae, EM, Perennial herb with rhizome. Inner shoot used as vegetable. A fine powder of leaves mixed with solidified sugar-cane juice is used in case of chronic piles.

Utricularia aurea Lour., Lentibulariaceae, SM, An insectivorous plant with yellow flowers. Fish food. Flowers with aesthetic value.

Vallisneria spiralis L., Hydrocharitaceae, SM, Perennial herb with white flowers. Food of fish. Aesthetic value.

Vernonia cinerea (L.) Less., "Sahadeva”, Asteraceae, EM, Erect herb with pink heads. Fodder, used for making fermenting cake.

Veronica anagallis-aquatica L., Scrophulariaceae, EM, Annual herb with white flowers. 